\title{
SHIPBUILDING
}

DOI https://doi.org/10.30525/978-9934-588-79-2-1.35

\section{ДОСЛІДЖЕННЯ ВПЛИВУ РЕЦИРКУЛЯЦІЇ ДИМОВИХ ГАЗІВ НА РОБОТУ СУДНОВОГО ДОПОМІЖНОГО КОТЛА}

\author{
Пацурковський П. А. \\ кандидат технічних наук, \\ асистент кафедри технічної теплофізики \\ та суднових паровиробних установок \\ Національного університету кораблебудування \\ імені адмірала Макарова \\ м. Миколаїв, Україна
}

В останнє десятиліття значно посилилися вимоги з боку Міжнародної морської організація (IMO) до викиду шкідливих токсичних речовин $\left(\mathrm{NO}_{\mathrm{x}}, \mathrm{SO}_{2}\right)$ в складі відпрацьованих газів суднових енергетичних установок [1]. 32016 набули чинності посилення норм у зонах контролю емісій оксидів азоту на 80\% (рівень Tier III). У зв'язку з цим потрібна розробка і впровадження на суднах методів зниження викидів забруднюючих речовин в атмосферу.

Актуальність роботи обумовлена відсутністю даних щодо впливу рециркуляції газів на показники економічності та екологічності роботи суднових допоміжних котлів.

Аналіз літературних даних показав, що одним з найбільш ефективних і дешевих методів зниження викидів оксидів азоту є метод рециркуляції відпрацьованих газів (табл.1).

Таблиця 1

Ефективність методів зниження викидів $\mathrm{NO}_{\mathrm{x}}$

\begin{tabular}{|c|c|c|c|c|c|}
\hline Метод & $\begin{array}{c}\text { Допалю- } \\
\text { вання } \\
\text { палива }\end{array}$ & $\begin{array}{c}\text { Зменшен- } \\
\text { ня над- } \\
\text { лишку } \\
\text { повітря }\end{array}$ & $\begin{array}{c}\text { Стадійна } \\
\text { подача } \\
\text { повітря }\end{array}$ & $\begin{array}{c}\text { Рециркуля- } \\
\text { ція димових } \\
\text { газів }\end{array}$ & $\begin{array}{c}\text { Впорскування } \\
\text { води або пари }\end{array}$ \\
\hline $\begin{array}{c}\text { Ефек- } \\
\text { тив- } \\
\text { ність, \% }\end{array}$ & 50 & 40 & 30 & 50 & 30 \\
\hline
\end{tabular}


Для оцінки впливу рециркуляції димових газів на технікоекономічні та екологічні показники роботи суднового допоміжного котла було розроблено розрахункову комп'ютерну модель, яка дозволяє визначати: адіабатну і середньоінтегральну температури в зоні активного горіння (ЗАГ), температури на виході з топки та відхідних газів котла, а також температуру змішування дуттєвого повітря і газів рециркуляції; паропродуктивність котла, теплосприйняття топки i конвективного паротвірного пучка; втрату теплоти з газами і коефіцієнт корисної дії котла; аеродинамічний опір газоповітряного тракту, продуктивність і потужність дуттєвого вентилятора; викиди оксидів азоту.

Тепловий та аеродинамічний розрахунки котла виконано на основі рекомендацій [1-4]. Для розрахунку виходу оксидів азоту використані рекомендації робіт $[5,6]$. В якості об'єкту дослідження прийнято судновий парової допоміжний котел Aalborg OM-TCi [1].

При теплових розрахунках було прийнято наступне:

1) теплові втрати від хімічної неповноти згоряння $0,5 \%$;

2) теплові втрати від зовнішнього охолодження котла $1,5 \%$;

3) коефіцієнт надлишку повітря прийнято 1,15 ;

4) теплова напруга топкового обсягу $800 \mathrm{\kappa BT} / \mathrm{m}^{3}$.

5) паливо - малосірчастий мазут М40 з нижчою теплотою згоряння $\mathrm{Q}_{\mathrm{H}}{ }^{\mathrm{p}}=39,8$ МДж/кг і вмістом азоту на робочу масу $0,4 \%$.

На рис.1 наведені графіки залежностей температур, що характеризують роботу топки: адіабатної, середньоінтегральної в ЗАГ і на виході $з$ топки в залежності від коефіцієнта рециркуляції. Як видно з графіків, рециркуляція димових газів в розмірі $20 \%$ призводить до зниження адіабатною температури в топці на $273^{\circ} \mathrm{C}$, середньоінтегральної температури в ЗАГ на $239{ }^{\circ} \mathrm{C}$ і температури газів на виході 3 топки - на $77^{\circ} \mathrm{C}$. Важливо відзначити, що відбувається значне зниження середньоінтегральної температури в ЗАГ, від якої значною мірою залежить утворення оксидів азоту. 


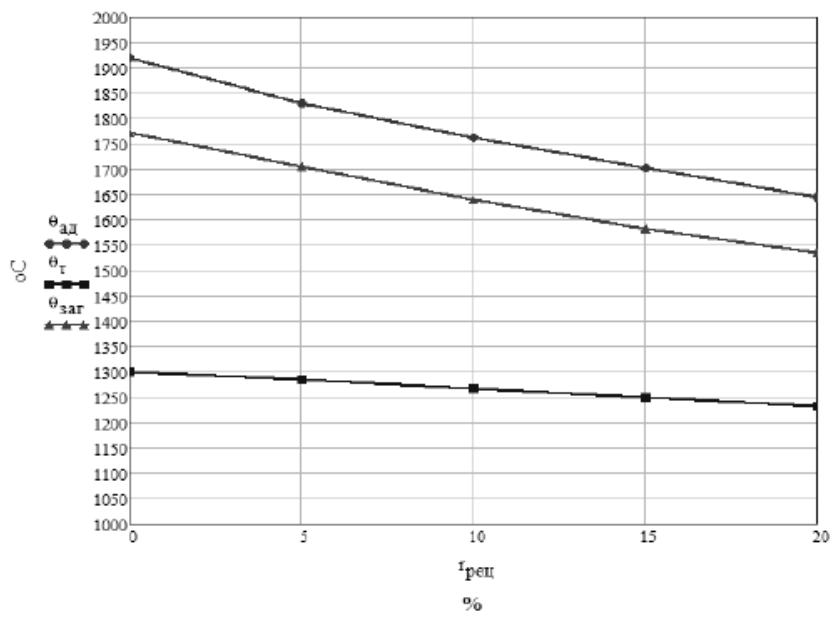

Рис. 1. Залежність адіабатною температури $\left(\theta_{\text {ад }}\right)$ на виході 3 топки $\left(\theta_{\mathrm{T}}\right)$ і середньоінтегральної температури в зоні активного горіння $\left(\theta_{\text {заг }}\right)$ від коефіціснта рециркуляції $\left(\mathrm{r}_{\text {рец}}\right)$

Встановлено, що температура відхідних газів котла підвищується на $11^{\circ} \mathrm{C}$, а температура газоповітряної суміші на вході в дуттєвий вентилятор - на $38^{\circ} \mathrm{C}$. Це в свою чергу призводить до зменшення коефіцієнта корисної дії котла з 89,2 до $88,7 \%$ (рис. 2).

Розрахунки показали, що рециркуляція газів і підвищення температури газоповітряної суміші призводить до значного зростання продуктивності дуттєвого вентилятора на 36,5\%. Зі збільшенням коефіцієнта рециркуляції ступінь зниження викидів оксидів азоту сповільнюється, а ступінь підвищення газового опору котла зростає (рис. 3), що обумовлено квадратичною залежністю газового опору котла від швидкості газів.

При коефіцієнті рециркуляції до $15 \%$ зниження викидів оксидів азоту досягає $44 \%$, а підвищення опору газоповітряного тракту котла досягає 25\%, що є прийнятним з економічної точки зору. 3 рис. 3 видно, що подальше підвищення ступеня рециркуляції газів в топку більше $15 \%$ призводить до досить істотного зростання газового опору котла, що є недоцільним з економічних міркувань. 


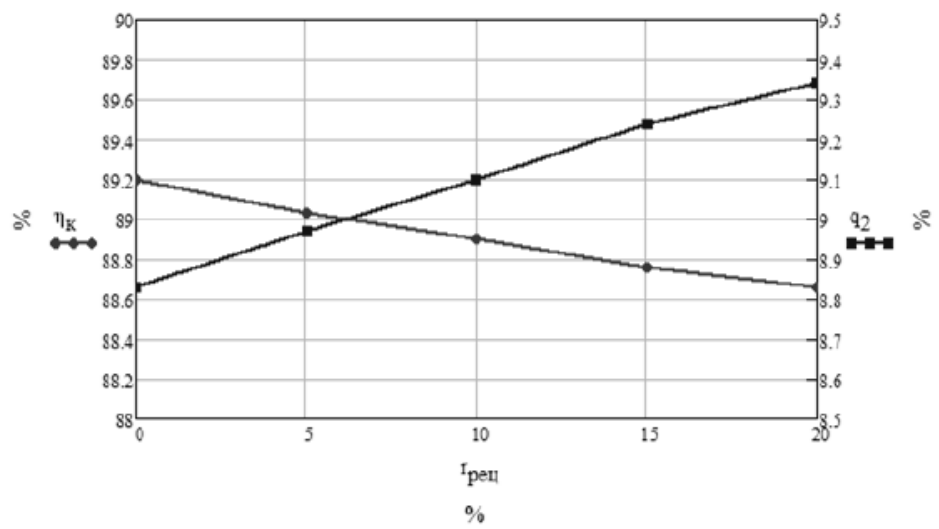

Рис. 2. Залежність коефіцієнта корисної дії котла $\left(\eta_{\kappa}\right)$ і втрати теплоти з газами $\left(\mathbf{q}_{2}\right)$ від коефіціснта рециркуляції $\left(\mathbf{r}_{\text {рец }}\right)$

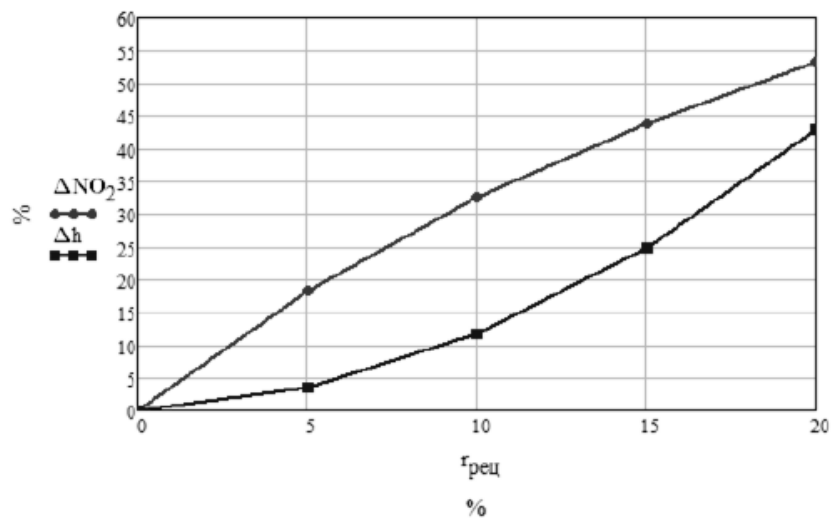

Рис. 3. Залежність зниження викидів окислів азоту $\left(\Delta \mathrm{NO}_{2}\right)$

і підвищення газового опору котла $(\Delta \mathrm{h})$ від ступеня рециркуляції газів в топку $\left(\mathrm{r}_{\text {рец }}\right)$

Таким чином, за результатами дослідження було встановлено, що оптимальний ступінь рециркуляції газів знаходиться в межах $10 \ldots 15 \%$, що відповідає зниженню викидів оксидів азоту в діапазоні від 33\% до $44 \%$. 


\section{Література:}

1. Спіфанов, О. А. Конструкції суднових котлів. Навчальний посібник. Миколаїв: НУК, 2016. 198 с.

2. Тепловой расчет котлов (нормативный метод). (1998). 3-е изд., переработанное и дополненное / РАО ЕС России, ВТИ, НПО ЦКТИ; [редкол.: А. А. Абрютин и др.]. СПб: Изд-во НПО ЦКТИ. 256 с.

3. Аэродинамический расчет котельних установок. (Нормативний метод). Л.: Энергия, 1977. 255 с.

4. Хряпченков, А. С. Судовые вспомогательные и утилизационные котлы: учебное пособие. 2-е изд., перераб. и доп. Ленинград: Судостроение, 1988. $296 \mathrm{c}$.

5. РД 153-34.02.304-2003. Методические указания по расчету выбросов оксидов азота с дымовыми газами котлов тепловых электростанций. Москва: ОАО «ВТИ», 2003. 42 с.

6. Таймаров, М. А., Чикляев, Д. Е. Образование термических окислов азота при сжигании газа. Вестник Казанского Технологического ун-та, Т. 16. № 23. 2013. С. 73-75. 